\title{
Research on animals and current UGC guidelines on animal dissection and experimentation: A critical analysis
}

\section{La investigación en animales y las directrices actuales de la UGC en la disección y experimentación animal: un análisis crítico}

\author{
Kuldeep Kaushik $^{\mathrm{a}, \mathrm{b}, *}$, Ravi Vaswani ${ }^{\mathrm{a}}$ \\ ${ }^{\text {a }}$ Centre for Ethics, Yenepoya University, Deralakatte, Mangalore, Karnataka 575018, India \\ ${ }^{\mathrm{b}}$ Department of Zoology, Dev Samaj College for Women, Ferozepur City, Punjab 152002, India
}

Received 5 April 2018; accepted 14 May 2018

Available online 15 June 2018

\begin{abstract}
Dissection and vivisection are two important activities in biological classes in order to understand the vital processes of life. They not only provide basic training for young learners, but also lay the foundation for all other research. Inhuman behavior toward laboratory animals drew the attention of the public worldwide, including many non-government organizations and animal lovers. They convinced some countries to issue strict guidelines for the use of animals for classroom dissection/experimental purposes. After receiving many complaints on unethical uses of animals for classroom dissection purposes, the University Grant Commission, New Delhi, issued new guidelines for the phasing out of dissection and animal experimentation in
\end{abstract}

\footnotetext{
Abbreviations: UGC, University Grant Commission; NGOs, Non-Government Organizations; MoEF, Ministry of Environment \& Forestry; MHRD, Ministry of Human Resource Development; DMC, Dissection Monitoring Committee; UG, Under Graduate; PG, Post Graduate; CPCSEA, Committee for the Purpose of Control and Supervision of Experiments on Animals; ICT, Information Communication Technology; IREC, Institute Research Ethics Committee; PCA Act, Prevention of Cruelty to Animals Act; Inter NICHE, is a NGO of International Network for Humane Education; I-CARE, Italy based NGO; Pfa, People for Animal, India based NGO; MORI, YouGov, ICM, are different independent agencies conducted the survey and opinion poll in UK.

* Corresponding author.

E-mail address: kaushik41738@yahoo.co.in (K. Kaushik).
} 
the zoology/life sciences curricula. In the present study the authors correlate the relevance and importance of animal dissections in teaching and research, and for the parallel development of medical and biological science. They conclude that animal experiments are vital to the future well-being of humans, and are morally permissible as long as they are conducted with high ethical standards. Animal experimentation and use of animals for dissection purposes are also justifiable, from various philosophical viewpoints. It appears that the guidelines issued by UGC are not based on serious deliberation on the bioethical dilemma.

(C) 2018 Centros Culturales de México, A.C. Published by Masson Doyma México S.A. All rights reserved.

Keywords: Bioethics; Animal experimentation; UGC; Zoology

\section{Resumen}

La disección y la vivisección son dos parámetros importantes en las clases de biología para comprender los procesos vitales de la vida de los seres vivos. No solo proporciona la práctica imprescindible a los estudiantes, sino que también permite establecer las bases para todas las demás investigaciones. El comportamiento inhumano hacia los animales de laboratorio ha llamado la atención del público en todo el mundo, así como de muchas organizaciones no gubernamentales defensoras de los animales. Convencieron a algunos países para que establecieran pautas estrictas sobre el uso de animales para la disección con fines experimentales en el aula. Después de recibir muchas quejas sobre usos no éticos de animales para las prácticas de disección en el aula, la University Grant Commission (Comisión de Becas Universitarias) de Nueva Delhi emitió una nueva directiva que suprimía, de manera escalonada, la disección y la experimentación animal en el currículo de zoología/ciencias de la vida. En el presente estudio, los autores relacionan la relevancia y la importancia de las disecciones de animales en docencia e investigación y para el desarrollo paralelo de la medicina y la biología. Concluyen que los experimentos con animales son vitales para el bienestar futuro de los humanos y que son moralmente permisibles, siempre y cuando se lleven a cabo con altos estándares éticos. La experimentación animal y el uso de animales con propósitos de disección también son justificables, desde varios puntos de vista filosóficos. Parece que la directriz emitida por la UGC no se basa en una seria deliberación sobre el dilema bioético.

(C) 2018 Centros Culturales de México, A.C. Publicado por Masson Doyma México S.A. Todos los derechos reservados.

Palabras clave: Bioética; Animal experimentación; UGC (Comisión de Becas Universitarias); Zoología 


\section{Introduction}

Animal experimentation and classroom dissection are important and basic features to enhance the existing knowledge of biological and medical research. Research plays a vital role in development of science $\&$ technology by the production and dissemination of valid, reliable and generalized knowledge. Knowledge means information organized according to justifiable social interest (Lolas, 2008). Progressive research and consistent evolution in the field of medical \& biological research setup new parameters in the field of advanced research. The genuine aspects of research always advocate the betterment of science and society. If we look carefully, there are certain pros \& cons which should be followed in order to have a fair conduct of research and these pros and cons logically lead to the formulation of certain rules and regulations that govern research.

Teaching and research activities are historically performed with the use of animals in search of knowledge and benefits both of them (Danielski, Barros, \& Carvalho, 2011). In many countries public give animal welfare great importance (Bert, Chmielewska, Hensel, Grune, \& Schonfelder, 2016). The famous dictum of the philosopher Jeremy Bentham, "the question is not, can they reason, or can they talk, but, can they suffer, is routinely wielded in defense of animal interest with the assumed positive answer to the latter question (Mehta, 2005)". Scientists have always tried to inculcate humane behavior in animal experiments but debate has renewed worldwide for animal welfare. Inhumane behavior toward lab animals has drawn the attention of public worldwide. Many NGO's and animal lovers usually oppose dissection in the classrooms. Some countries have made strict guidelines to use animals for experimental purpose.

\section{Conceptual sketch \& review}

Medical and biological sciences are important constituents that provide the new measure for healthcare and welfare of the society. The scientists of these fields are continuously working to unfold the complicated mystery of life. Research on animal models not only laid the foundation but also played a vital role in many scientific and medical developments of the past century and continues to aid our understanding of various diseases. Since, animals are frequently used in research investigations; they play an important role in unfolding the vital information about human and animal life processes. The development of new medical regimens, treatment and drugs all are 
made possible by experiment on animal models. There is no doubt that advancement in healthcare and medicine logically provides better quality of life worldwide.

Keeping this in mind, the present study is designed to analyze (i) the role of animal experimentation and its relevance to the development of biological \& medical science (ii) use of animals in teaching and research and their attendant bioethical dilemmas and (iii) the UGC guidelines on the issues of discontinuation of dissection and animal experimentation in Zoology/Life Science in a phased manner, under following subheading.

\section{History of animal dissection}

Dissection is a very important process in the study of anatomical \& physiological aspects of internal body part of animals accessed through cutting and/or incision of dead animals. It is reported that various scientist were engaged in animal dissection right from ancient times. Galen's work with apes and pigs led to the discovery that veins carried blood. In 1628, an English doctor William Harvey used animals to discover how blood circulated in the body. Two-thirds of Nobel laureates in physiology or medicine since 1901 have relied on animal data for their research (Burggren \& Warburton, 2007). In medical research human beings are believed and or/considered to be most important and the process of vivi-section if necessary should be used to improve their lives. Rats, mice and other rodents make up $95 \%$ of all animals used, and primate's make up one-third of one percent of all animals used. Beside the genetic constitution, there are lots of anatomical similarity between animals and human being as they have a same set of organs like heart, liver, kidney, lungs and other tissues. They possess the similar internal body mechanism and or/physiology like, blood circulation, respiration, nervous, endocrine system etc. So these similarities logically make some animals prone to dissection in the laboratory and provide basic training to the young scholars in relevant field of life sciences. This is the foundation of basic training in the field of medical \& biological research.

\section{Animal in education (classroom dissection)}

Dissection is the act of cutting into and examining a dead animal to serve as a prominent educational tool for teaching the fundaments of zoology or related field i.e., taxonomy, physiology, anatomy and other related subjects of life sciences. Students dissect preserved animals throughout all levels of biological studies, from 
Table 1

Name of laboratory animals and their industrial relation.

\begin{tabular}{lll}
\hline Sr. no & Name of animal & Industrial use \\
\hline 1 & Earthworm & Widely used in therapeutic and nutritional purposes \\
2 & Cockroach & Part of pest control \\
3 & Prawn & Govt. promotes prawn farming (part of food Industries) \\
4 & Pila & Part of pest control \\
5 & Herdmania & Sea bloom \\
6 & Fish & Fishing is promoted by all over the world for human consumption \\
& & (part of food industries) \\
7 & Frog & Legs are exported at large scale (used in various French and Chinese \\
& cuisine) \\
8 & Lizard & Part of pest control \\
9 & Rat & Part of pest control \\
\hline
\end{tabular}

higher secondary onwards. Medical schools also perform dissections; however, the students often perform dissections on human cadavers. Veterinary schools' curricula involve animal dissection and the use of live animals through a number of different ways (http://www.neavs.org/education/overview. Accessed 15.09.16).

Presently Ministry of Environment \& Forestry (MoEF), Govt. of India, has banned the dissection and vivisection in biology classes and it is observed that various universities and state education board have modified the syllabi of different classes accordingly. As per the syllabi of various universities of India, following animals, which are mentioned in Table 1, have been deleted from classroom dissection. Nevertheless, these are still widely used in/by various industries or its products.

\section{Current UGC guidelines on animal dissection}

The University Grants Commission (UGC) of India is a statutory body set up by the Government of India, in accordance with the UGC Act 1956, and is empowered with coordination, determination and maintenance of standards of higher education.

UGC received many representations regarding the review on the use of animals in education. In consideration of the seriousness of the issue, in November 2011, UGC issued new guidelines for the discontinuation of dissection and animal experimentation in Zoology/Life Science in a phased manner. In the pre-amble of these guidelines, it was mentioned that for the classroom dissection, most of these animal were caught from the wild, and their indiscriminate removal from natural habitat disrupted the 
biodiversity and ecological balance. It was also stated that demand for the dissection specimens increases pressure on threatened species. Besides, it has also admitted that laws/regulations/guidelines about animals and their welfare were not taken to $\operatorname{cog}$ nizance while prescribing animal use in the curriculum. On the basis of above cited facts and certain other reasons an expert committee was constituted by UGC. The Committee recommended that the UGC should take up the issue of discontinuation of dissection and animal's experimentation in Zoology/Life Science in a phased manner with the acquisition of appropriate technology and the development of human resource for the same. The recommendation came up in the form (i) immediate action and (ii) long term action (http://www.ugc.ac.in/pdfnews/6686154_guideline.pdf. Accessed 15.09.16), which was approved by UGC and Ministry of Human Resource Development (MHRD) and these bodies issued following guidelines which are applicable to all teaching and research departments which deal with the use of animal dissection in teaching and learning process.

\section{Immediate action}

\section{Recommendation 1}

All institutes of higher education have to strictly adhere to the Wild Life Protection Act, 1972 and the Prevention of Cruelty to Animals Acts, 1960.

As per the guideline of recommendation no.1, as far as possible, experiments on animals are not to be performed merely for the purpose of acquiring manual skill and not to use animals protected under the Wildlife Protection Acts, 1972, particularly frogs belonging to genus "Rana" and any elasmobranch fish in laboratory exercise. Further, it is also recommended that "Animal Ethics" should be included as a chapter in an appropriate course study.

\section{Recommendation 2}

All Institute of Higher Education have to constitute "Dissection Monitoring Committee (DMC)" to look into the use of animals.

Beside the composition and power of DMC as per the UGC guidelines (page no.-256), it is clearly mentioned at serial no. $7 \& 8$ that, DMC shall approve and/or review the use of animals in dissection/experiments for laboratory exercises, within the purview of UGC guidelines and it shall be the responsibility of DMC to ensure that the animals that are permitted to be used for dissection/experiment in the guideline, 
are procured from ethical sources, and not removed from the wild for these purposes, and transported to the laboratory without stress or strain to the animals if alive, and anesthetized appropriately if they are to be used in dissection. According to Sr. No.9, the institute shall maintain appropriate records of procurement of animals, their transport if alive, number of animals used, use of anesthesia/euthanasia if applicable.

\section{Recommendation 3}

For both under graduate (UG) and post graduate (PG) programs, there shall be reduction in number of animals for dissection and experimentation as well as in number of species with all ethical consideration. Preferences shall be given to laboratory bred animal models.

As per the guidelines of recommendation no. 3, animals used in experimentation should be procured from the breeders approved by Committee for the Purpose of Control and Supervision of Experiments on Animals (CPCSEA).

\section{Recommendation 4}

For UG: "only one species" to be adopted for "demonstration only" by the faculty and "student should not do any dissection". In lieu of this, the curriculum must be developed to encourage students to take up field work.

Recommendation no. 4 was meant for UG students only, as per the suggested guidelines, students (UG) shall not be required to dissect any animal, teachers shall only demonstrate the dissection of one or more aspect of anatomy, which the students will observe and record. Coming to examination, if at all found necessary, students may be required to flag/label specific parts in the specimens already dissected by the teachers and kept ready. It is further suggested that, the Board of Study should list the animals/animal grouping in the curriculum, in a flexible framework in such a way that the final choice of the specimens, and not the number and category, will be at the users end.

Plastinated dissected specimens or digital alternatives (DigiFrog, BioLab Frog, ProDissector Frog, etc.) may be used in the laboratory, where the animal's anatomy is highlighted. Secondly, students shall only observe the animals and make record of observation during field visit; the animals shall neither be killed nor removed from their natural habitat to conserve biodiversity. 


\section{Recommendation 5}

For PG: Students shall have the option to perform dissection of "selected species" as per the curriculum or to have a project related to biodiversity/biosystematics, etc.

As per the guidelines, those who opt for dissection, the curriculum may prescribe the dissection of very few designated specimens, may be one from invertebrate and one from chordates for instance. In the choice of animal (s) here, the guidelines no. 4.1 (page no.-257) will strictly apply. These students, the recommendation further suggested, could use computer simulation learning devices and avoid use of animals in physiological practical.

\section{Long term action}

\section{Recommendation 1}

Development of Human Resources through training programs toward adopting alternatives modalities for animal dissection.

Use of digital alternatives is prescribed in the guidelines, since these digital alternatives are information communication technology (ICT) based, hence, teachers need to be trained in these alternatives. It is further suggested that, the UGC shall sponsor a 3-5 day dedicated workshop for this purpose through Academic Staff College/University Departments/College, with the help of organization with experience/expertise in the field.

\section{Recommendation 2}

Software development for alternative modalities for animal dissection, experimentation and dissemination.

As per the guidelines, newer software/simulation contextualized to the Indian context need to develop and these modalities to be available in the downloadable form to the institution without cost, as an aspect of INFLIBNET. It is also mentioned that, UGC will organize a brain-storming session for an interaction between expert in dissection and/or experiment and software developers to be identified appropriately, and then arrange to develop the software either in direct role of UGC or through nodal agency/organization that will be identified. 


\section{Recommendation 3}

Empowering Zoology/Life Science departments with appropriate ICT for implementing the above recommendation.

To facilitate the recommendation no. 3, all departments dealing with animals for teaching and learning should be empowered with infrastructure to adopt the ICT required for the purpose, for which additional assistance will be provided by UGC.

\section{Recommendation 4}

Curriculum related to invertebrate, vertebrate, etc., to be enriched with biosystematics, population dynamics, evolution and biodiversity

As per related guidelines, the subject mentioned in the recommendation should be integrated as part of the curriculum of respective disciplines. The UGC will evolve a model curriculum in this regard.

The guidelines were issued by the expert committee constituted by UGC. Dr. BK Sharma, Dr. MA Akbarsha and Dr. Rangnath were the members of that expert committee. Two years later on, Professor Ved Prakash, Chairman, UGC issued a demi-official letter (D.O. No.-1-80/2014, Cm) dated 20th February, 2014 to the vice-chancellors (VCs) and Directors of different institute to ensure the strict adherence to Prevention of Cruelty Act, 1960 and the Wildlife Protection Act, 1972 and compliance of the guidelines issued by UGC dated on 22-11-2011 on its website (www.ugc.ac.in). After some time, another demi-official letter was issued by the Secretary, UGC wide D.O. No. F. 14-6/2014(CPP-II). He mentioned that besides many factors of enormous degradation of biodiversity, one of the most significant reasons is the brutal use of animal species for dissection purpose at post secondary levels of education. He further urged all universities to stop dissection of animal at undergraduate and post graduate level. For the first time a UGC official proposed a ban on animal's dissection at post graduate level. Certain amended guidelines were published in notification no. 14-6/2014 (CPP-II), issued by the expert committee constituted by UGC during 2011. The guideline no. 5, on page no. 258-259, of the notification issued on $22 / 11 / 2011$, was replaced with a new guideline by which dissection is completely banned at PG level. In reference to guideline no. 6, page no. 259 of earlier guideline, where UGC levied the responsibility for capacity building through training program in the form of 3-5 days workshops through Academic Staff College/University 
departments/College an amendment in the existing regulation was made. In its new guideline it is simply mentioned that Higher Educational Institute may conduct these workshop with the help of organization with experience/expertise in the field.

Bioethics \& it relation to use of animals in teaching \& research

Bioethics is the branch of science which deals with ethical issues in medical \& biological work. Presently, bioethics is not simply application of philosophical notions to scientific problems or a new formulation of classical professional deontology. It is a dialogic form of deliberation considering social interests and the cultural or religious norms about what is proper, what is good and what is just. The word bioethics is just like a canopy to cover different attempts to humanize the scientific enterprises. Fritz Jahr who coined the word 'Bioethics', examined the animals and plant welfare with a theological point of view, considered a humane treatment of living being (Jahr, 1927). When he coined the term bioethics, he did not clearly address scientific research on animal and most of what has later been said, however, is anticipated in his writings. Paraphrasing Immanuel Kant with the categorical imperative, Jahr suggested that all living beings were entitled to respect and should be treated not as means but as ends in themselves (Engel, 2004; Sass, 2007).

Public have different opinion on the laboratory use of animals and if we look through a bioethical microscope, the scenario observed will be totally different. Albeit, based on moral value bioethics varies from person to person. The dialogical nature of bioethics has created new social institutions or reshaped old ones. Before the microscopy of the present issue, following benefit should be consider i.e.,

1. Dissection opens a dimension of critical analysis regarding the structure and function of particular organ and its interconnection with other organ.

2. Hands-on training develops proficiency.

3. Inculcates scientific temperament $\&$ logics in the young scholar.

4. Gives an opportunity to the students to develop respect and admiration for life $\&$ the loss represented by the death of an animal, can teach ethics, laboratory experiences in life science classes should not result in the improper treatment of animals. 
On the basis of above cited conviction as well as its importance, it's not hard to say that the dissection helps in the progression and development of life science.

\section{Current scenario of biological research}

Anatomical, physiological as well as cytological similarity makes animals the best suitable and easily available option for research. It is also reported that, chimpanzees share $99 \%$ of their genetic similarity (deoxyribonucleic acid) with humans, and mice share $98 \%$ with humans. Not only are they genetic similar but also possess the same number of genes i.e., 30,000 (Emes, Goodstadt, Winter, Chris, \& Ponting, 2003). On the basis of these similarities, there is no adequate alternative to test on a living, whole body system. Whether animals are a "model" for the human species, there appears to be consensus that the "ideal model may not exist", but that there is the most appropriate available model (Paixão \& Schramm, 1999). In vitro study also plays an important role in the study of various biological phenomena but does not allow scientists to study the interrelated processes of the internal milieu of the body influenced by central nervous system, endocrine systems, and immune system.

During the process of scientific up-gradation by mean of animal's experimentation, if we look deeply, animals are also equally benefited. Animals have been saved from various diseases through the testing of vaccinations; without this testing, millions of animals would have died from rabies, canineparvo virus, tetanus, distemper, feline leukemia and other cancers, anthrax, infectious hepatitis virus, heartworm, brain tumors, and birth defects (7thgradehumanities.weebly.com/uploads/../pro__con_arguments_animal_testing.doc. Accessed 15.09.16). It is also observed that, animal testing has saved many endangered species from extinction like the black-footed ferret, the California condor, and the tamarins of Brazil. Koalas are being tested with vaccines for chlamydia, a disease which has contributed to them to become endangered in some parts of Australia. There is no doubt that animal testing has helped the creation of many life-saving cures and treatments and it will continue if the Government of India endorses animal testing (7thgradehumanities.weebly.com/uploads/../pro__con_arguments_animal_testing.doc. Accessed 15.09.16). Various physiologists consider that animal experiments are still very important in biomedical research and also for certain confirmatery test. They agree that the animal will for the time being remain indispensible in biomedical research, although its role will shift in the direction of the confirmation of result obtained by animal free methods (Hemdriksen, 2006). According to Bernard, the greatest physiologist: "Animal experimentation is an integral, absolute right. The physiologist is 
not a man of the world; he is a wise man, a man involved and absorbed by a scientific idea that he pursues. He does not hear the cry of the animals, neither does he see the blood that flows. He only sees life and observes how organisms hide problems that he seeks to unveil" (Bernard \& Kaufman, 1997).

Since last few years, certain State Board and Universities that conduct senior secondary, UG and PG level examination have "banned" dissection and replace the same by ICT programs. Many academicians felt that this is not an appropriate step. These academicians feel that the study of science must essentially be supported by experiments and practicals involving dissection (Murthy, 2000). There is difference between animal abusing and doing experiments in scientifically ethical manner \& conditions. Ethical conditions are no doubt based on morality, but the involvement of bioethical issues in animal experimentation is totally different from these conditions.

Ban on animal dissection \& experiments seem to be a unilateral decision of the government. Movement on various issues related to animals experimentation and dissection in teaching and research are also observed in the scientific community the form of seminar/symposium or panel discussion. A panel discussion "Should animal experiments be stopped in India?" was held on 5th December 1998 at Banaras Hindu University during the 10th Annual Conference of the Physiological Society of India. The panel recommended that the experiments on animals are absolutely necessary for proper training of science students, especially the medical students. Though some experiments, especially for drug testing, could be done away by alternate methods, it is not possible to avoid animal experiments completely (Murthy, 2000).

Albeit, tremendous advancement in medical and biological science has taken place, the animal activists worldwide do not appreciate the use of animals in biological studies. Scientists are now finding out certain alternatives to animal experimentation in biomedical research. In India, first time a plenary session on animal alternative in teaching and testing was held at Indian Science Congress dated on 6th January 2012 (Akbarsha, Zeeshan, \& Pereira, 2012). Presently, various scientific journals are now exploring the alternatives of animal experiments, these efforts no-doubt open up a new arena of research in the field of life science.

\section{Ethics committee \& CPCSEA}

Institute research ethics committees (IREC) have an important role to play in ensuring the ethical standards and scientific merit of research involving human as well as 
animal subjects. It is responsibility of IREC to provide competent review of all ethical aspects of the research project, undertake review free from bias and influence and provide advice to the researchers on all aspects of welfare and safety of research participants. However, in scientific process, humane behavior is expected from the research personnel. IREC evaluate the possible risks to the subjects with proper justification as well as expected benefits but scientific evaluation should be completed before ethical evaluation

It is usually observed that various established universities of India have appointed senior faculty member to constitute the IREC, for conducting research smoothly and without any compromise. Even in some institutes, the existence of IREC is observed on the papers only. Due to deficient of trained professional in IREC, research work and/or proposal are easily passed without proper scrutinizing. In various institute and/or universities, there are no regulations in basic research forcing scientists to perform animal tests. To merely fulfill the requirement of the curriculum or degree, by (usually) free choice, questions are posed and hypotheses are examined which, in many cases, can only be answered by means of animal tests. It is also observed in few cases that researchers are simply not aware of the limitations of the animal experiment as such and many animal experiments are dramatically "under-powered", i.e. carried out with groups that are too small to allow conclusions to be drawn from the outcome (Gruber \& Hartung, 2004). This type of research aptitude logically leads the minds of policy maker to find out the alternative of animal experimentation.

The CPCSEA in India is a statutory body of the government of India formed by an act of the Indian parliament. The committee comprises of seven nominees - three nominees appointed by CPCSEA and the remaining four from educational institutes. The CPCSEA draws its powers from the Prevention of Cruelty to Animals (PCA) Act of 1960 which states that the duty of the committee is "to take all such measures as may be necessary to ensure that animals are not subject to unnecessary pain or suffering before, during or after the performance of experiments on them". Based on the PCA act, the MoEF has issued guidelines to the University Grants Commission, Ministry of Health and Family Welfare, Pharmacy Council of India and the Medical Council of India to discontinue dissection and experiments with live animals in universities, colleges, research institutes, hospitals, laboratories and instead use alternatives like computer simulation. The guidelines were framed based on the duties of the CPCSEA, which has been constituted under the provisions of Section 15 of the Prevention of Cruelty to Animals Act (1960). All establishments engaged in research and education involving animals, are required to comply with the various guidelines, norms and stipulations set out 
by CPCSEA. Mangal Jain, Nominee of CPCSEA, said that "The animal experiments should be stopped in all institutes except for the purpose of new molecular research. Sometimes, in laboratories, a lot of work is repeated and animals become unnecessary victims. Only scientists researching on a new molecular theory can experiment on animals. In medical and pharmacy colleges, there is unwanted cruelty toward animals which can be avoided. These guidelines mention imprisonment for five years and monetary penalty", as mentioned in the leading Indian print media (http://timesofindia.indiatimes.com/india/Govt-bans-use-of-live-animals-foreducation-research/articleshow/12696452.cms. Accessed 15.09.16).

\section{Discussion}

In teaching and research, many scientific activities and experiments are performed using various biological resources in order to deepen knowledge of a subject; one of them is the use of animals for didactic and scientific purposes in search of knowledge and benefits to both people and animals (Danielski et al., 2011). Dissection \& vivisection have its own role in the development and understanding of biological processes. According to Paixão, "The assertion that the use of animals in teaching is fundamental for animal experiments to continue to exist, does not confer moral legitimacy to either party; it just establishes the logic of the relationship between them" (Paixao, 2008).

The process of animals experimentation in teaching \& research is well justified through scientific advancements and it is always considered a prerequisite to improving the social welfare through improving the quality of life of all living being. However, it is necessary to improve and implement mechanisms to regulate the knowledge-oriented use of animals. Different ethical approaches address the issue of animal use in teaching and research, but recent studies carried out by Danielski et al. (2011), referenced in the two following areas (Lima, 2008) i.e.,

I. Deontology - a radical approach which does not accept, under any circumstances, the use of animals in procedures that will cause them some kind of suffering.

II. Utilitarianism - whereby animal use is accepted as long as it does not subject animals to unnecessary suffering (Danielski et al., 2011). 
In context of animals experiment, Lima stated that when we accept the acquisition of scientific knowledge + humane methods as objective criteria, we deconstruct old beliefs about the use of animals in experimentation and favor men, without excluding the perception of experimental animals as sentient beings (Lima, 2008).

Biodiversity conservation and environmental issues are presently on the top priorities of federal governments of various countries. It is believed that natural resources have an inherent value which should not be destroyed. There are various views and theories toward nature which play an important role in the development of applied ethics related to environment. When we extend ethical scope of human being toward nature, then we observe three related philosophical theories on environment ethics: anthropocentrism, biocentrism and ecocentrism (Surmeli \& Saka, 2013).

Anthropocentrism: It usually considers humans to be the most important creature on the planet earth and other forms of life to be important only to the extent that they affect humans or can be useful to humans. In an anthropocentric ethic, nature has moral consideration because degrading or preserving nature can in turn harm or benefit humans.

Biocentrism: The biocentric worldview considers humans to be a particular species of animal, without greater intrinsic value than any of the other species of organisms that occur on earth.

Ecocentrism: Along with the biocentrism, one considers humans as a natural component of earth's ecosystem and that humans have a right to the products and services of ecosystems in order to sustain themselves and their societies.

In context to present investigation entitled "Research on animals \& current UGC guideline on animal dissection \& experimentation: A critical analysis", if we look at the medical development for the betterment of human as well social well being, biocentrism has faced criticism for a number of reasons. They have been criticized for its individualism; emphasizing too much on the importance of individual life and neglecting the importance of collective groups, such as an ecosystem (Carlos, 2011). It is also observed that the concern that biocentrism is an anti-human paradigm and that it will not hesitate to sacrifice human well-being for the greater good (Schiffman, 2011).

In the pre-amble of UGC Guidelines (issued dated on 22-11-2011, page no. 253), it is mentioned that most of the animals are caught from wild, and their indiscriminate 
removal from the natural habitat disrupts the biodiversity and ecological balance, thus, use of animal in dissection has come to be a factor compounding with habitat loss, pollution and climate change in depletion of animals population. If we look this matter through an ethical bioscope, anthropocentrism and ecocentrism are two ways of understanding an extension of ethics to nature. It is considered that nature is to be an instrument for human ends without taking into reasonable account the needs and rights of other life forms and earth systems themselves. This worldview is often associated with a utilitarian attitude toward nature.

Various Indian universities and their affiliated colleges are the stake holders for the professional \& personal development of the nation, and all action governed by UGC, directly influences their academic curriculums. Yet, alternative to animal experiments opens a new vista in the biological science. In vitro experiments, computer simulation, and other alternatives are developing, but the importance of animal experimentation in futuristic development in life science must not be ignored (Rai \& Kaushik, 2018). Otherwise, the academic lobby as well as society will pay for it later on. The new guideline issued by UGC for the discontinuation of dissection and animal experimentation in Zoology/Life Science in a phased manner seems to be a dark regulation in the progressive journey of science \& research. During the analysis of this guideline, a well known phrase by John Stuart Mill comes to mind i.e., "Every great movement must experience three stages: ridicule, discussion, adoption" (Paixão \& Schramm, 1999; Regan, 1983).

In the context of global scientific concern based on the trends of humane uses of animals experimentation in teaching \& research, it would have been appropriate if UGC's notification dated 22nd November 2011, would have come out as a directive rather than a stringent norms. Doing the same provides enough flexibility to next to the authority. It is also observed that various Indian universities have immediately revised the curriculum. The word revision does not seem to be appropriate. Instead of revision, it is observed that Board of Studies of various state universities, edit/curtail the curriculum. Secondly, it is also observed that till date, as per the recommendation of UGC, the chapter 'Animals Ethics' is not included in various biological programs. And If we are talking about growth enrollment ratio, 90\% are registered with colleges affiliated with state level university. Since UGC has already banned dissection at UG and PG level, so there does not seem to be any need of constituting the Dissection Monitoring Committee (DMC) at college level besides it offers research programs, and the recommendation \& guideline no-2 has no significance on monitoring the same. These graduate and post graduate students are serving and 
training the nation without an appropriate knowledge of dissection and the word 'Animal Ethics' ironically is still out of syllabi.

According to stated guidelines only one species is permitted to be adopted for the demonstration to UG students and there is no dissection work for UG students, but PG students will have the option to perform dissection on 'selected species' only. The guidelines issued recently dated on 1st August 2014 in notification no. 14-6/2014 (CPP-II), have enforced a complete ban on animal dissection. As per the earlier guideline, UGC levied the responsibility for capacity building through training program in the form of 3-5 days workshops through Academic Staff College/University departments/College, but in the recently issued guideline, UGC has got rid of the extra financial burden in capacity building merely by quoting that the higher educational Institute may conduct these workshop with the help of organization with experience/expertise in the field. It is not expected from UGC to pass on the duty to higher educational institute on these global issues. UGC has banned the animal dissection, so it is its moral responsibility to provide alternatives training in appropriate manner through academic staff college/university departments.

It is also observed that one of the members of expert committee have a conflict of interest, as he is associated with the animal alternatives movement for well over a decade. He has been propagating the message of alternatives in India, in collaboration with many NGOs worldwide from United Kingdom (InterNICHE), Italy (I-CARE), and India (PfA). UGC should also justify the selection of its peer review committee because the impact of these guidelines on teaching and research will be long lasting. According to Feijo in a learning environment where teachers and students interact as they question whether or not animals should be used, the responses to such debate acquire paramount importance as they will guide future actions of future professionals whose decisions may or may not be influenced by their respect for life and non-human animals (Feijó, 2005). Therefore, more reflection should be made on the use of animals for teaching purposes because of the resulting impact on students' professional development. It is also astonishing that during the recommendation of these guideline, UGC official used the words 'brutal use of animal species for dissection purpose' is the question mark on the integrity of concerned faculty members (http://www.icmr.nic.in/bioethics/cc_biothics/presentations/sym_pune/For\%20PGs/ Animal\%20ethics.pdf. Accessed 15.09.16).

To find out the importance of animals research in prevalent society in United Kingdom (UK), opinion poll conducted by MORI, YouGov and ICM (all different independent agencies in UK) on the topic of role of animals' research, reveal that there 
is a good understanding and attitude of British People toward animal experimentation (http://www.hasindia.org/VCD/Animal\%20Experiments\%20in\%20India.pdf. Animal experimentation in India, Dossier submitted by Animal Defender international \& National antivivisection Society to CPCSEA. Accessed 15.09.16). It is observed that more than $85 \%$ is ready to accept the use of animals in medical research if the research is for serious medical purpose, suffering is minimized and/or alternative are fully considered (Festing \& Wilkinson, 2007). However, it is believed that the training of future biologists cannot be accomplished in alternative models, but in animals (Feijo, Sanders, Centurion, Rodrigues, \& Carla, 2008). Guerra also suggested that the decreased use of animals in scientific experimentation or in undergraduate education does not result from the belief that such practices are expendable and meaningless to the academic training of students; for example, medical students without previous training on animals will experience real difficulties later (Guerra, 2004).

The wave of restriction on animal's experimentation is observed worldwide; even some countries issued strict guideline on the current issues. The replacement of animals in various countries is not only a matter of ethics but also a legal matter. It is expected that these guidelines may come out as a hurdle in the development. There is, therefore, a need to provide them certain degree of freedom and adequate facilities to use animals and/or human samples wherever necessary. Extent of the degree of freedom and knowledge of ethical issue related to medical and biological research are a major dilemma.

On the basis of above cited facts \& discussion and through study of the present topic "Research on Animals \& Current UGC Guideline on Animal Dissection \& Experimentation: A Critical Analysis" it might be recommended to an appropriate authority that

1. Chapter on 'Animals Ethics' and the guidelines issued by an appropriate authorities for laboratory Animal Facility should be included in every curriculum related to Biological/Medical Science.

2. There should be a specific \& mandatory refresher course to the faculty of life science.

3. A specific certificate course should be mandatory for the animal house and laboratory staff.

4. List of endangered species should be provided to the Curriculum Designing Committee of the university i.e., Board of Studies. 
5. Instead of ban on animal's dissection reduction and refinement of experiment (as per the suggestion of expert committee) should be practiced.

6. At UG level, dissection should be performed and demonstrated by teacher only and PG level there should be certain degree of freedom. Board of Studies should specifically recommend farming animals (fish, prawn, chick, etc.) and targeted animals of pest control (flies, cockroach, rats, etc.).

7. As per the bio-geography of the institute there should be certain degree of freedom and according to availability of the animals, specimen in type study, \& dissection should be changed.

8. Animals should be procured from ethical sources in appropriate manner.

9. Data of animals experiment should be maintained by appropriate authorities.

10. The dissection should be knowledge oriented rather than skill oriented.

\section{Conclusions}

On the basis of the present study and the relevance of the importance of animals dissection in teaching $\&$ research and parallel development of medical and biological science, it can be concluded that animal experiments are vital to the future well being of humans and, as long as they are conducted to high ethical standards, the entire concept is also justifiable, from a utilitarian viewpoint. Human act of indiscriminate removal from the natural habitat disrupt the biodiversity and ecological balance, is justified by the anthropocentrism, but it is highly unethical. It appears that the guideline issued by UGC is not based on any bioethical dilemma which was one of major objective of the study.

\section{Authors' contributions}

K.K. conceived the study, participated in its design, analyzed the available data and helped to draft and edit the manuscript. R.V. helped to design, draft and edit the manuscript, revised it critically for important intellectual content; and given the final approval of the version to be published. All authors read and approved the final manuscript. 


\section{Ethics approval and consent to participate}

The authors declare that this work is carried out within an appropriate ethical framework.

\section{Consent for publication}

Not applicable.

\section{Availability of data and materials}

The datasets supporting the conclusions of this article are included within the article.

\section{Funding}

No funding sources.

\section{Conflicts of interest}

The authors declare that the research was conducted in the absence of any commercial or financial relationships that could be construed as real or potential conflict of interest.

\section{References}

Akbarsha, M. A., Zeeshan, M., \& Pereira, S. (2012). Alternatives discussed at Indian Science Congress. Alternatives to Animal Experimentation, 29, 216-218.

Bernard, N. D., \& Kaufman, S. R. (1997). Animal research is wasteful and misleading. Scientific American, 276, 64-66.

Bert, B., Chmielewska, J., Hensel, A., Grune, B., \& Schonfelder, J. (2016). The animal experimentation quandary: Stuck between legislation and scientific freedom. EMBO Reports, 17, 790-792.

Burggren, W. W., \& Warburton, S. (2007). Amphibians as animal models for laboratory research in physiology. ILAR Journal, 48, 260-269.

Carlos, S. (2011). Biocentrism: Green ethics and philosophy: An A-to-Z guide.pp. 57. Thousand Oaks, California: SAGE Publications.

Danielski, J. C. R., Barros, D. M., \& Carvalho, H. A. H. O. (2011). Animal use for teaching and research purposes: Pros and cons. Revista Electrônica de Comunicação, Informação \& Inovação em Saúde, 5, 72-84. 
Emes, R. D., Goodstadt, L., Winter, E. E., Chris, P., \& Ponting, C. P. (2003). Comparison of the genomes of human and mouse lays the foundation of genome zoology. Human Molecular Genetics, 12, 701-709.

Engel, E. M. (2004). O desafio das biotécnicas para a ética e a antropología. Veritas, 5, 205-228.

Feijó, A. G. S. (2005). Teaching and research in animal model: Bioethics: A panoramic view. Porto Alegre: Edipucrs.

Feijo, A. G. S., Sanders, A., Centurion, A. D., Rodrigues, G. A., \& Carla, H. A. (2008). Analysis of ethical indicators of animal use in scientific investigation and education among university sample from health area and biological sciences. Scientia Medica, 18, 10-19.

Festing, S., \& Wilkinson, R. (2007). The ethics of animal research. EMBO Reports, 8, 526-530.

Gruber, F. P., \& Hartung, T. (2004). Alternatives to animal experimentation in basic research. Alternatives to Animal Experimentation, 21, 3-31.

Guerra, R. F. (2004). The use of animals in scientific research. Impulso Piracicaba, 15, 87-102.

Hemdriksen, C. F. (2006). Developments in the area of animal experiments in biomedical research. Nederlands Tijdschrift Voor Geneeskunde, 150, 2857-2862.

Jahr, F. (1927). Bio-Ethik. Eine Umschau über die ethischen Beziehungen des Menschen zu Tier und Pflanze. Kosmos Handweiser für Naturfreunde, 24, 2-4.

Lima, W. T. (2008). Entendimento humano da experimentação animal. Ciência e Cultura, 60, 25-32.

Lolas, F. (2008). Bioethics and animal research. A personal perspective and a note on the contribution of Fritz Jahr. Biological Research, 41, 119-123.

Mehta, N. (2005). Research using animals: An ethical dilemma. Indian Journal of Physiology and Pharmacology, $49,1-7$.

Murthy, K. R. (2000). Animal experimentation and research in India. Journal of Postgraduate Medicine, 46, 251-252.

Paixao, R. L. (2008). Replacing methods on the use of live animals in teaching. Rethinking what we learn from animals in teaching. Ciência Veterinária nos Trópicos, 11, 88-91.

Paixão, R. L., \& Schramm, F. R. (1999). Ethics and animal experimentation: What is debated? Cadernos de Saúde Pública, 15, 99-110.

Rai, J., \& Kaushik, K. (2018). Reduction of animal sacrifice in biomedical science \& research through alternative design of animal experiments. Saudi Pharmaceutical Journal, http://dx.doi.org/10.1016/j.jsps.2018.03.006

Regan, T. (1983). The case for animal rights. pp. 279. Los Angeles: University of California Press.

Sass, H. M. (2007). Fritz Jahr's concept of bioethics. Kennedy Institute Ethics Journal, 17, 279-295.

Schiffman, H. S. (2011). Environmental policy \& law (general), environmental technology, policy \& management: Green issues and debates: An A-to-Z guide. pp. 32. Thousand Oaks, California: SAGE Publications.

Surmeli, H., \& Saka, M. (2013). Preservice teachers' anthropocentric, biocentric, and ecocentric environmental ethics approaches. International Journal of Academic Research, 5, 159-163. 